\title{
Developing Singapore as an international medical centre
}

Ngiam Tong Dow

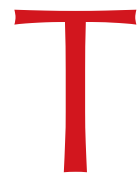

hank you for giving me the great privilege of addressing SMA members, doctors and members of the medical profession. In fact, the first time I spoke to a group of doctors was at a meeting organised by the Obstetrical and Gynaecological Society of Singapore, but I think you've given me a larger platform to convey my thoughts today.

In a Straits Times article in January 2013, I enjoined Singaporeans to forget first world hype. It is a complete delusion on our part to think that Singapore can become a first world city alongside New York, London, Tokyo, and in the near future, Shanghai. It will be more realistic for us to aim to be a leading second-upper tier city like Zurich, Boston, Sydney, Tel Aviv and Hong Kong. I think that in the world of global competition, we must know our place and compete with our strong points.

I shall begin with Singapore's development as an international financial centre from the 1970s. It was sparked off by an unconscious strategic decision to move from a productionbased to a knowledge-based economy. Singapore had exploited the time slot between the closing of the Tokyo market and the opening of the London market to trade in foreign exchange. Today, according to the latest report, we are ranked the third largest foreign exchange market trader in the world. This is no mean feat for a small economy, without any natural, continentalsized economic hinterland, unlike New York and Shanghai.

In my view, the defining characteristic of an international financial centre is its ability to attract powerful mathematical minds that are capable of creating esoteric derivative models for trading hedge funds. The best Oxbridge minds head for the city of London, while the best Ivy League minds gravitate to Wall Street. Today, the question I would like to pose to this distinguished audience of doctors is simply this: can Singapore become a leading international medical centre?

Despite the tremendous strides we have made in medical education, Singapore is, in my view, still very much a work in progress. Dealing as it were with human lives, Medicine is far more complex than high finance. Our quest to be a centre of excellence for Medicine began in the 1980s when I was chairing the Economic Development Board (EDB). Even then, the economic signals were coming in loud and clear. Singapore simply could not grow as a production-based economy, however advanced our manufacturing technology was. A productionbased economy depends greatly on land, labour and capital, but Singapore is very limited in these resources; in fact, there is a shortage. We had to move into a knowledge-based economy because I believed it could be one of our strong points. One of the promising knowledge sectors is Medicine. Traditionally, our best and brightest 18-year-olds compete their guts out for places in a medical school, so I thought Medicine was a natural for Singapore. However, I was disappointed when our administrators looked within instead of outside the box. The doctor-to-population ratio was set at 1:600, and the aim was to raise the ratio to $1: 450$.

After strong political pressure brought to bear through EDB's access to the Prime Minister's Office, the Ministry of Health $(\mathrm{MOH})$ agreed to double the enrolment of National University of Singapore (NUS) medical school from 125 to 250 students, spread over a period of five years. EDB was roundly chastised by our critics for this. Fears of hordes of underemployed doctors practicing dubious Medicine filled the air. Sadly, these critics had missed the wood for the trees. Instead of focusing only on a limited domestic market, EDB had advocated that Singapore train enough doctors to meet the rising demand from neighbouring countries' growing middle class, who were willing to pay for better medical services than that available in their own countries. Only the super-rich could afford Harley Street in the UK or Mayo Clinic in the US.

Thankfully, reality prevailed over uninformed ignorance and prejudice years later. Today, we have established not one, but three medical schools, namely the original NUS Yong Loo Lin School of Medicine, Duke-NUS Graduate Medical School, and Nanyang Technological University and Imperial College London's Lee Kong Chian School of Medicine. Collectively, these three medical schools should be educating and training around 1,000 doctors annually. This group of highly trained medical graduates should provide enough thrust to propel Singapore to grow into a leading world-class international medical centre.

Medical centres, unlike financial centres, are far more complex to structure and organise. This was vividly brought home to me when I was hospitalised recently in Singapore General Hospital's (SGH) high dependency ward after an unfortunate car accident. Co-Director of SGH's Trauma Service, A/Prof Wong Merng Koon was my chief surgeon. He was able to call upon all SGH specialist departments to collaborate in treating this critically ill patient, namely myself. It was an impressive performance of command and control. If I may say so, such close coordination is possible only in our six public hospitals, namely SGH, National University Hospital, Tan Tock Seng Hospital, Changi General Hospital, and the new Khoo Teck Puat and Ng Teng Fong hospitals.

My stay in SGH brought home to me another reality. No matter how outstanding our surgeons and physicians may be, they would not be able to function without the services of key supporting departments and paramedical personnel such 
as radiologists. Although helmed by our own doctors, SGH's radiology department was staffed at the technical level by foreign-trained technicians from China, India and the Philippines. It is not an exaggeration to observe that without foreign-trained manpower, the Trauma Service and other surgical departments will have to close down.

The second reality is even more compelling. Nurses are at the frontline of patient care, hour after hour, shift after shift. To dismiss nursing as a low-level job is to do our nurses, both local and foreign, a great disservice, even if it was stated as a footnote in the Population White Paper. [Editor's note: this reference in a footnote to the White Paper was later deleted, and the Government apologised for its inclusion.] In our crowded wards today, I have observed that some $90 \%$ of nursing staff are from the Philippines, China, India, Vietnam and Burma. Though they fill an immediate gap, my concern is that we are just taking a short-term stopgap approach. Our school of nursing was closed down three decades ago for reasons I am unable to fathom. Although four of our polytechnics and Institutes of Technical Education offer diploma courses in nursing, we have no comprehensive plan to train nurses who are the heart of patient medical care.

While our private sector is adept in bringing foreign patients into Singapore, it is basically aiming to sell specialist space. Mount Elizabeth Orchard is a shining example of this success. In my view, if Singapore is to grow into a world class medical centre, $\mathrm{MOH}$ should convene a meeting of all stakeholders to plot out how this ambition can be realised. Until then, Singapore remains a work in progress in international Medicine. Medical services create more multiplier effects for the rest of the economy than financial services. Regional budget airlines provide air connections for medical tourists, who also stay in our hotels and shop at our malls. The economies of scale created by medical tourism will help to keep gross national expenditure on healthcare in check. For some time now, we have tried to keep domestic health expenditure at, I believe, $4 \%$ of gross domestic product (GDP), but this will rise inexorably with a rapidly ageing population.

At this juncture, I would like to explain a little about technical economic concepts. There are three approaches to measuring GDP - the income, expenditure, and output approaches. If you go by the income approach, the figure would be more than $4 \%$, as medical tourism will, I think, add another $2 \%$ back to our GDP. Therefore, the rise of medical cost in Singapore can be restrained because of businesses from foreign patients who are paying for our services. When calculating health expenditure, economists should decide which of the three approaches to take. Economies of scale created by medical tourism will help to keep in check gross national expenditure on healthcare. Although inexorably rising domestic health expenditure is inevitable with a rapidly ageing population, serving the greater market will help us to restrain the cost of medical care because we will have a larger economy.

Fortunately, our government had the foresight to introduce copayment for public health services. Copayment is one of our strong pillars of public finance and the best guarantee against the likelihood of Singapore becoming a welfare state, like Britain with its National Health Service. There is now a committee set up to consider how we can subsidise the poor. I think we cannot run away from the fact that payment is necessary to keep the insurance sovereign. As one of the directors of Raffles Health Insurance, I can tell you we are running at a loss month after month. In insurance, the reality is that the older one gets, the higher the premium, and if taxpayers' money is utilised to pay for it, then we run the risk of sliding into the British health service model, which is nothing to be proud of. It is therefore very difficult to implement a national health insurance scheme, and that is why the Government has to work this out carefully.

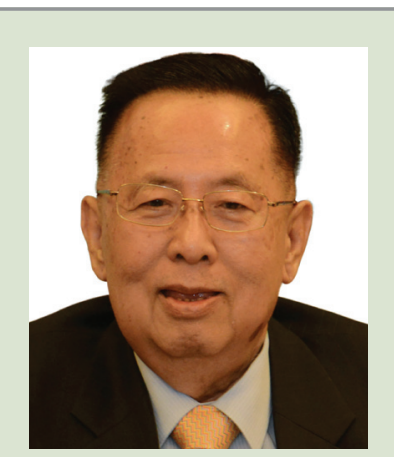

\section{About the Lecturer}

In a civil service career that spanned 40 years (1959-1999), Mr Ngiam Tong Dow had served as Permanent Secretary in the Prime Minister's Office; Ministries of Finance; Trade \& Industry; Communications; and National Development. Concurrently, he also chaired the Singapore Economic Development Board, Sentosa Development Corp, Development Bank of Singapore, Sheng-Li Holdings (now restructured to become Singapore Technologies Holdings), and Singapore Telephone Board (now merged with the Telecommunications Department to become the Telecommunications Authority of Singapore).

Upon retirement, Mr Ngiam was appointed Chairman of the Central Provident Fund Board and Housing Development Board. He was also served as an independent director on the boards of four listed public companies: Singapore Press Holdings, Overseas Union Bank, United Overseas Bank, and Yeo Hiap Seng Ltd. He continues to serve as an independent director of Yeo Hiap Seng Ltd today.

For public service, he was awarded the Public Administration Medal (Gold), the Meritorious Service Medal, the Distinguished Service Order, and the Long Service Medal. He obtained a Bachelor of Arts (First Class Honours) in Economics from the University of Malaya in 1959, and subsequently, Masters in Public Administration from Harvard University in 1963. His knowledge domain is development economics.

The 2013 SMA Lecture was delivered on 26 October 2013 at the Grand Copthorne Waterfront Hotel. The citation of Mr Ngiam Tong Dow was delivered by Dr Charles Toh, Honorary Member of Singapore Medical Association. A copy of the citation is published in the November 2013 issue of SMA News. 